\title{
STATE CONTROL OVER POLITICAL ORGANIZATIONS: FIRST AMENDMENT CHECKS ON POWERS OF REGULATION
}

THE extensive regulatory powers of states over corporations and unincorporated associations provide an instrument of untested constitutionality for restraining the advocacy of ideas. A state's control may take the form of denying corporate charters to associations, ${ }^{1}$ of keeping corporations chartered elsewhere from functioning within its borders, ${ }^{2}$ and of subjecting corporations and unincorporated associations to registration statutes requiring publication of membership lists. ${ }^{3}$ Several states have recently invoked their regulatory powers to halt the activities of the National Association for the Advancement of Colored People, a New York corporation engaged in improving rights of Negroes through the mobilization of public opinion. 4 In pursuance of their power to exclude foreign corporations, Alabama and Texas have permanently enjoined the NAACP from conducting activities within their jurisdictions.5 Louisiana has banned local unincorporated chapters as well as the parent corporation because of their failure to file membership lists-a requirement that the NAACP resisted for fear of exposing members to official and private sanctions. ${ }^{6}$

1. See notes 30-54 infra and accompanying text.

2. See notes 55-74 infra and accompanying text.

3. See notes 75-103 infra and accompanying text.

4. The NAACP's legal arm, the Legal Defense and Educational Fund, Inc., is a separate corporation from its informative or "political" branch. The Alabama action names only the NAACP; but in Texas both entities have been enjoined. See decrees cited note 5 infra.

5. Alabama ex rel. Patterson v. NAACP, 15th Jud. Cir., Ala., June 1, 1956, reported in 1 RACE Relations L. ReP. 707 (1956); Texas v. NAACP, Southern School News, Nov. 1956, p. 8, cols. $2-5$.

The Alabama action was in the nature of a quo warranto suit to oust the NAACP for acts contrary to public policy such as employment of Negroes to enroll in the University of Alabama, organization of a boycott to end segregation on busses and failure to register as a foreign corporation. Since the court enjoined the NAACP not only from conducting any further business, but also from registering in order to qualify to do business, the action cannot be construed as one to compel registration. Southern School News, July, 1956, p. 10 , col. 4 .

Texas alleged inter alia that the NAACP attempted to register Negroes in schools segregated in accordance with state law. N.Y. Times, Nov. 22, 1956, p. 38, col. 4.

6. Louisiana $c x$ rel. Le Blanc v. Lewis, No. 55899, 19th Jud. K. La., April 24, 1956, reported in 1 Race Relations L. Rep. 571 (1956). See also Southern School News, Dec. 1956 , p. 15 , col. 4 (after much procedural difficulty the case was permanently removed to federal district court).

For explanation of the NAACP's objections to filing, see Letter by Roy Wilkins, Exec. Sec'y of NAACP, to N.Y. Times, June 10, 1956, \& 10; Southern School News, Jan., 1957, p. 12, col. 2. In New Orleans, where reprisals are less likely to occur, the local branch has agreed to file its membership lists. N.Y. Times, Dec. 31, 1956, p. 16, col. 4.

Threatened with a similar action in North Carolina, the NAACP applied for a judicial declaration that it is not required to register under N.C. GEN. STAT. \$ 55-118 (Supp. 1955) 
These injunctions constitute a direct restraint on the right to promote a cause by joint action; because of the significant role which interest groups play in the dissemination of ideas, the powers of states to impose such restrictions must be sharply delineated. ${ }^{7}$ Courts have employed the First Amendment, as included in the Fourteenth, to nullify other types of state-imposed curtailments upon the right of individuals to associate and the right of associations to communicate. ${ }^{8}$ Rather than focus exclusively on the merits of the NAACP cases, this Comment will consider the overall question of the extent to which the Fourteenth Amendment undercuts a state's power to impair organized advocacy by denying corporate charters, excluding foreign corporations, and requiring disclosure of members of organizations. ${ }^{\ominus}$

\section{Political Organizations as "Persons" Entitled to Free Speech}

Any limitations that may exist on state powers over organizations engaged in influencing public opinion must rest on the assumption that the Fourteenth Amendment endows such organizations with the right of free speech. Freedom of speech and of the press are incorporated in the word "liberty" of the Fourteenth Amendment's provision that no state shall "deprive any person of life, liberty, or property, without due process of law. . .."10 Although courts have

(foreign corporation statute) and id. $\$ \$ 120-48$ to 55 (membership lists required of all organizations influencing legislation and public opinion). NAACP y. Eure, Sup. Ct. N.C., March 12, 1956, reported in 1. RACE RELATtons I. REP. 405 (1956).

Alabama has sought membership lists through a bill of discovery to determine whether the NAACP is doing business in that state. Alabama $e x$ rel. Patterson v. NAACP, N.Y. Times, July 26,1956, p. 11, cols. 1-4 ( $\$ 10,000$ fine for willful contempt in failing to produce membership lists). The fine, later raised to $\$ 100,000$, was upheld by the Alabama Supreme Court. Id., Dec. 7, 1956, p. 22, col. 6.

In Georgia production of records containing the names of members of the NAACP was compelled for a tax investigation. See note 95 infra and accompanying text.

Other Southern states are contemplating restrictive measures against the NAACP. See Southern School News, Jan. 1957, p. 1, col. 3. Events occurring after January 12, 1957, are not covered by this Comment.

7. See note 37 infra and accompanying text. Political scientists have stressed the ineffectiveness of uncoordinated action by individuals in a complex political process. See Horn, Groups and tee Constirution 14-15 (1956) ; Laski, Liberty in the Modern State 130 (1934) ; Schlessinger, Sr., Biography of a Nation of Joiners, 50 AMr. Hrst. Rev. 1 (1.944).

8. E.g., De Jonge v. Oregon, 299 U.S. 353 (1937) (punishment for participating in non-violent meeting under auspices of organization advocating violence held unconstitutional) ; Grosjeán v. American Press Co., 297 U.S. 233 (1936) (taxing to curtail activities of newspaper corporation held unconstitutional).

9. This Comment will not discuss political parties and the powers of states to regulate such activities as primaries and party contributions.

10. U.S. Const. amend. XIV, $\S 1$. All freedoms protected by the First Amendment from abridgment by Congress are among the fundamental "liberties" protected by the due process clause of the Fourteenth Amendment from impairment by the states. Gitlow v. New York, 268 U.S. 652, 666 (1925) (dictum; speech) ; Cantwell v. Connecticut, 310 U.S. 296 (1940) (religion) ; De Jonge v. Oregon, 299 U.S. 353 (1937) (assembly) ; Near v. Minnesota, 283 U.S. 697 (1931) (press). 
always held corporations to be "persons" entitled to protection of property,"11 three early cases, none of which involved a free speech issue, stated that the guarantee of liberty extends only to natural persons. ${ }^{12}$ Even while creating this dichotomy, however, the Supreme Court protected the "liberty" of an educational corporation by stretching the meaning of "property."13 And in Grosjean v. American Press Co. ${ }^{14}$ the Court accorded the guarantee of freedom of press to a newspaper corporation inhibited by state regulation. This ruling has been followed in a number of cases concerning the communications industry ${ }^{15}$ in

11. Louis K. Liggett Co. v. Baldridge, 278 U.S. 105 (1928) ; Kentucky Finance Corp. v. Paramount Auto Exchange Corp., 262 U.S. 544, 550 (1923); Smyth v. Ames, 169 U.S. 466, 522 (1898). But sce Wheeling Steel Corp. v. Glander, 337 U.S. 562, 576 (1949) (dissenting opinion by Douglas, J.) ; Connecticut Gen. Life Ins. Co. v. Johnson, 303 U.S. 77, 83, 85 (1938) (dissenting opinion by Black, J.).

Corporations are not citizens within the privileges and immunities clause of the Fourteenth Amendment. Paul v. Virginia, 75 U.S. (8 Wall.) 168 (1869); Orient Ins. Co. v. Daggs, 172 U.S. 557, 561 (1899) ; Hague v. CIO, 307 U.S. 496, 514 (1939).

Corporations are also "persons" entitled to equal protection of the laws. Wheeling Steel Corp. v. Glander, 337 U.S. 562 (1949) ; Santa Clara County v. Southern P.R.R., 118 U.S. 394 (1877). But cf. Williams v. Baltimore, 289 U.S. 36 (1933) (municipal corporations); Newark v. New Jersey, 262 U.S. 192 (1923) (same). This affords little protection to foreign corporations, however, because they are not "within the jurisdiction" and entitled to equal protection until they qualify to do business there. Hanover Fire Ins. Co. v. Harding, 272 U.S. 494 (1926) ; Crescent Cotton Oil Co. v. Mississippi, 257 U.S. 129 (1921) ; Sully v. American Nat'l Bank, 178 U.S. 289 (1900) ; Blake v. McClung, 172 U.S. 239, 260 (1898); Nugent v. Brown, 315 Pa. 345, 173 A.2d 177 (1934). But see Kentucky Finance Corp. v. Paramount Auto Exchange Corp., 262 U.S. 544 (1923) (not qualified to do business but held entitled to equal protection when entered state to replevin property). Accordingly the Supreme Court has held that a license tax that is a prerequisite to admission of a corporation to a state cannot be challenged on equal protection grounds, while a tax imposed upon a corporation which already has the right to do business in a state can be attacked. Hanover Fire Ins. Co. v. Harding, supra; Southern Ry. v. Greene, 216 U.S. 396 (1909).

12. Pierce v. Society of Sisters, 263 U.S. 510, 535 (1925) (educational corporation not entitled to "liberty") ; Western Turf Ass'n v. Greenberg, 204 U.S. 359, 363 (1907) (business corporation, same) ; Northwestern Nat"l Life Ins. Co. v. Riggs, 203 U.S. 243, 255 (1906). In Nortliwestern Justice Harlan cited no precedent; in Western Turf he cited Northwestern.

13. Pierce v. Society of Sisters, 263 U.S. 510,535 (1925). An Oregon statute requiring all children to attend public school was held to deprive a private institution of its property without due process of law. Although such a statute is on its face a denial of liberty, the property clause was invoked, thus bypassing the two Harlan decisions, note 12 silpra. For a suggestion that the right to free speech by a radio station or the right to free press by a newspaper might be protected as a property right, see Note, 48 HARv. L. REv. 507 (1935).

14. 297 U.S. 233,244 (1936).

15. Joseph Burstyn, Inc. v. Wilson, 343 U.S. 495 (1952) (motion picture corporation); Pennekamp v. Florida, 328 U.S. 331 (1946) (newspaper corporation); Bridges v. California, 314 U.S. 252 (1941) (same). The issue of whether the corporation was a "person" was not discussed by the majority in any of the above cases. Justice Frankfurter, dissenting in Bridges at 281, stated inter alia that corporations cannot claim liberty and that the majority was "strangely silent" on the issue. But see Pennekamp v. Florida, supra (concurring opinion). 
one the Court granted a motion picture corporation protection under the guarantee of freedom of speech as well as freedom of the press. ${ }^{16}$ These opinions do not reveal whether the Court has completely abandoned the restrictive definition of "person" or has merely carved out an exception for newspapers and motion pictures. Although Grosjean suggests that corporations are entitled to all the safeguards of the due process clause, ${ }^{17}$ a political organization's right to free speech may still be in doubt as a result of the decision in Hague v. CIO,18 the last Supreme Court case explicitly treating this issue.

In Hague the Supreme Court completely obscured the status of organizations under the "liberty" clause. An unincorporated association, its officers and a corporation sought to enjoin enforcement of a municipal ordinance on grounds that it violated their right of free speech. The Supreme Court dismissed the association and the corporation as parties. Two Justices of the seven-man Court held that the organizations were not "citizens" entitled to privileges and immunities $;^{19}$ two others held, without distinguishing Grosjean, that the organizations had no right of free speech under the Fourteenth Amendment. ${ }^{20}$ But the Court permitted the officers of the association to maintain the action; the ordinance was declared unconstitutional on its face, even though it had apparently prevented the officers only from conducting activities on behalf of the association. ${ }^{21}$ Subsequent cases have also granted Fourteenth Amendment protection to individuals'speaking in their capacity as agents of unincorporated associations. ${ }^{22}$

The rationale underlying these holdings, that agents are natural persons vested with the right of free speech by the Fourteenth Amendment, extends to the agents of corporations as well. ${ }^{23}$ This rationale, however, renders the view that corporations and associations are not "persons" meaningless: since organizations can speak only through their agents, denial of free speech to or-

16. Joseph Burstyn, Inc. v. Wilson, 343 U.S. 495 (1952).

17. 297 U.S. at 244 : "But a corporation is a 'person' within the meaning of the equal protection and due process of law clauses, which are the clauses involved here." For this proposition the Court cited cases involving deprivations of property and ignored the cases establishing a contrary rule for deprivations of liberty. See cases cited note 12 supra.

18. 307 U.S. 496 (1939).

19. Id. at 514. These Justices did not reach the due process question.

20. Id. at 527. The Justices relied on the three cases holding that corporations were not "persons" entitled to liberty, see note 12 supra, and did not even cite Grosjean.

21. The individual respondents were restrained from "labor organization activities" including distribution of printed matter and the holding of public meetings. 307 U.S. at 501-02.

22. Thomas v. Collins, 323 U.S. 516 (1945) (organizer of union); Thornhill v. Alabama, 310 U.S. 88 (1940) (union picketer).

23. It may be argued that an association is juristically the sum of its members, all of whom are persons entitled to "liberty," and therefore the association has the right of free speech. See Brief for Respondents, pp. 150-52, Hague v. CIO, 307 U.S. 496 (1939). This interpretation is negated by Hague, however, which treated the unincorporated association as a fictional person along with the American Civil Liberties Union, the corporation dismissed from the case. 
ganizations is ineffective if their individual agents are still protected. ${ }^{24}$ Courts must interpret the Fourteenth Amendment in one of two ways : either an association or corporation is not a person entitled to free speech and its agents acting in an official capacity cannot claim protection; or such organizations are persons entitled to free speech protection, and the organizations as well as their individual agents, have standing to enforce this right. ${ }^{25}$

From the standpoint of constitutional interpretation and public policy, the construction that organizations have a right of free speech is preferable. The history of the Fourteenth Amendment reveals no intent to define "person" differently for protecting property than for protecting liberty. ${ }^{26}$ From a policy perspective, the First Amendment's object of an open political process cannot be realized unless organizations are considered persons entitled to liberty. Thus a recognition that there would be no freedom of press without protection of newspaper corporations must underlie the Grosjean decision. ${ }^{27}$ Similarly, in

24. The holding remains as a procedural limitation on the corporation's capacity to sue, however. In some cases it may be necessary for the corporation rather than its agents to maintain a suit. For example, assume that a state confiscates allegedly obscene books of a corporation. The individual agents of the corporation have no property rights in the books and hence cannot sue. A similar situation exists where the corporation is fined for publishing the book. But in both of these cases the sanction takes the form of a deprivation of property, and thus the corporation, a person for protection of property, would be able to claim that the abridgment of speech constituted a denial of due process. See notes 11 . and 13 supra and accompanying text.

25. A more consistent approach is taken in Fifth Amendment cases. A corporation cannot claim the privilege against self-incrimination. Oklahoma Press Publishing Co. v. Walling, 327 U.S. 186 (1946) ; Hale v. Henkel, 201 U.S. 43 (1906). Courts have implemented this rule by holding that corporate officers cannot refuse to produce corporate documents in their custody on grounds that they might incriminate themselves and the corporation. United States v. White, 322 U.S. 694 (1944) (president of union); Wilson v. United States, 221 U.S. 361 (1911) (president of corporation). The courts have realized that the denial of the privilege against self-incrimination to corporations could be defeated if officers acting in their official capacity could assert the privilege. See Wilson v. United States, supra at 384-85.

Significantly, however, the denial of the privilege against self-incrimination rests not on the theory that corporations are not "persons" within the Fifth Amendment, but on the assumption that the privilege was meant to protect individuals from forced disclosure.

26. There has been considerable historical debate as to whether corporations are "persons." The courts, however, have resolved the issue insofar as corporations are entitled to property and equal protection of the laws. See note 11 supra. A review of the history of the drafting of the amendment reveals no indication that some "persons" were to be entitled to property and not to liberty. On the contrary, draftsmen stated that the amendment was to protect "natural and inherent rights" - a philosophy which points up "life, liberty, and property" as a bundle of rights as opposed to three separate protections for three types of "persons." Graham, The Conspiracy Theory of the Fourteenth Amendment, 47 Yale L.J. 371, 397 (1937), 48 Yale L.J. 171 (1938) ; Flack, The Adoptron of tHe Fourteenta Amendment (1908); Taylor, The Orugin and Growth of the AmeriCan Constitution (1911).

27. See note 14 supra and accompanying text. In 1937, the year after the Grosjean decision, it was reported that three-fourths of the publishers of daily and Sunday newspapers in the United States were corporate entities. See Brief for Respondents, pp. 151-52, Hague v. CIO, 307 U.S. 496 (1939). 
view of the large number of incorporated and unincorporated pressure groups, 28 political organizations, as well as their individual members, must be protected if the political process is to be free from state restraint. Political organizations - corporations or unincorporated associations-should therefore be allowed to invoke First Amendment safeguards through the Fourteenth Amendment.0 It must then be seen to what extent the right of free speech limits a state's exercise of regulatory powers.

\section{The RIgHT to InCORPORATE}

The common law view of unincorporated associations was not conducive to their growth and efficient operation. Not recognized as legal entities, associations could not hold and convey property or sue in their own name. ${ }^{30}$ Rather, property could be maintained only by cumbersome procedures of joint or trustee ownership $;^{31}$ and except in equity all members had to join as parties in order to bring suit. ${ }^{2}$ In addition, expansion of membership was restricted by the risk of personal liability for debts incurred by associations. ${ }^{33}$ Midway through the nineteenth century, commercial units demanded a form of organization that would both limit liability of investors and facilitate the conduct of business. ${ }^{34}$ Incorporation, which had hitherto been granted sparingly, fulfilled these needs and has become the dominant form of commercial organization. ${ }^{3 n}$ Associations that engage to a substantial extent in influencing public opinion have tended to follow the example of business units. Thus, even where statutes

28. See note 37 infra and accompanying text.

29. FED. R. CIv. P. 17(b) (1) confers capacity to sue and be sued on unincorporated associations "for the purpose of enforcing for or against it a substantive right existing under the Constitution or laws of the United States. ..." But even before the adoption of this provision, the Supreme Court held that unions were to be considered entities for the purpose of suits governed by federal law. United Mine Workers v. Coronado Coal Co., 259 U.S. 344, 391 (1922). See International Longshoremen's Union v. Ackerman, 82 F. Supp. 65, 122-23 (D. Hawaii 1949) (unincorporated union considered "person" entitled to free speech; Hague not followed), rew'd on other grounds, 187 F.2d 860 (9th Cir. 1951).

30. Right to hold property: 3 AMERICAN LAw of Property $\$ 12,7 \$$ (Casner ed. 1954 Supp.) ; Wrightington, Unincorporated Assoctations and Business Trusts 336-37 (2d ed. 1923).

Right to sue: Nightingale v. Barney, 4 Iowa 106 (1853) (Masonic lodge); Pickett v. Walsh, 192 Mass. 572,78 N.E. 753 (1906) (trade union); Maisch v. Order of Americans, 223 Pa. 199, 72 Atl. 528 (1909) ; Wrightington, op. cit. supra at 425-36.

31. 4 American Law of Property $\$ 18.50$ (Casner ed. 1954 Supp.).

32. WRIGHTINGTON, ap. cit. sutpra note 30 , at $425-26$. In equity, a suit brought by members on behalf of themselves and other members of the class united in interest could be maintained. Id. at 430 .

33. Members of unincorporated associations are personally liable for the debts of the association on agency grounds. Security First Nat'1 Bank v. Cooper, 62 Cal. App. 2d 653, 145 P.2d 722 (1944); Hale v. Hirsch, 205 App. Div. 308, 199 N.Y. Supp. 514 (1st Dep't 1923) ; see Martin v. Curran, 303 N.Y. 276, 101 N.E.2d 683 (1951) (common law modified by statute); Wrightington, op. cit. supra note 30, at 282-390.

34. Berle \& Means, The Modern Corporation and Private Property 10-17 (1932).

35. Id. at 17 . 
have removed some of the common law disabilities of unincorporated associations, ${ }^{36}$ political organizations have chosen the corporate form. As a result of this movement, a basic layer of the political process is now composed of incorporated pressure groups. ${ }^{37}$

Although barriers to incorporation have been eliminated for commercial enterprises, they still exist for political associations. Traditionally, incorporation has been regarded as a privilege that a state may grant or deny on its own terns..$^{38}$ Competing with one another to attract industry, states have made this privilege readily available to businesses. ${ }^{39}$ Thus all states have general incorporation laws that permit commercial enterprises to incorporate by complying substantially with easily-met statutory standards. ${ }^{40}$ But in many states nonprofit assaciations are subject to special incorporation laws that vest administrative officials or judges with discretion to deny incorporation. ${ }^{41}$ Although no

36. Right to sue: e.g., Conn. Gen. Stat. $\$ 7797$ (1949); N.J. Stat. Ann. 2A-64-1 (Supp. 1955) ; VA. Cone ANN. \$ 8-66 (Supp. 1956).

Right to hold property: e.g., N.Y. MEMBERSHIP CORP. LAw $\$ 21$ (court approval necessary for sale); PA. Stat. ANn. tit. 15, $\$ 2851-308$ (Purdon 1955) (approval by majority of members necessary to acquire and dispose of realty). But many such statutes are not board enough to cover political associations. E.g., Wyo. Conpr. Stat. ANn. $\S 44907$ (Supp. 1955) (excepts political associations).

Although statutes have not conferred limited liability upon members of unincorporated nonprofit associations, the common law, which requires that a creditor prove that the member sought to be charged had authorized the debt-producing act, has operated as a functional substitute. See Balrantine, Corporations § 2a (rev. ed. 1946).

37. For example, the national organization or local chapters of the American Legion, Veterans of Foreign Wars, National Association of Manufacturers, American Civil Liberties Union and NAACP are incorporated.

38. Ashley v. Ryan, 153 U.S. 436, 441 (1893) (business corporation); Pacific Gas \& Elec. Co. v. State, 214 Ca1. 369, 375, 6 P.2d 78, 81 (1931) (same); see Louis K. Liggett Co. v. Lee, 288 U.S. 517, 544-45, 548 (1933) (dissenting opinion by Brandeis, J.) (same); Henderson, Foreign Corporations in American Constitutional law 3-35 (1918).

39. "The race was not one of diligence but of laxity. Incorporation under such laws was possible and the great independent states yielded in order not to lose wholly the prospect of revenue and the control incident to domestic incorporation." Louis $\mathrm{K}$. Liggett Co. v. Lee, 288 U.S. 517, 541, 557 (1933) (Brandeis, J., dissenting).

40. 1 P-H CORP. SeRv. I 1102; see Berre \& MEANs, op. cit. supra note 34, at 135-38.

Limiting standards such as maximum authorized capital no longer exist in incorporation laws, 1 P-H CORP. SERv. II 9001-51, although this was once a universal requirement, Lotis K. Liggett Co. v. Lee, 288 U.S. 517, 541, 550 (1933) (dissenting opinion). At most some states require a minimum capital to begin business, e.g., Fla. GEN. CoRp. LAw $\$ 608.03$ (d) (Supp. 1956) ( $\$ 500)$.

41. Discretion in Courts: Ga. Code Ann. $\$ 22-203$ (Supp. 1955); Me Rev. Stat. Ann. c. 54, $\S 1$ (Supp. 1955); Mo. Ann. Stat. $\$ 352.060$ (Supp. 1956) ; N.Y. Menrbersmip Corp. Law $\$ 10$; Pa. Stat. ANN. tit. 15, $\$ 2851-207$ (Purdon 1955); Va. Code ANN. \$13-222 (Supp. 1956).

Discretion in Administrative Officials: Iowa Code ANN. $\$ 504.1$ (Supp. 1956); Mass. Ann. Laws c. 180, $\$ 5$ (Supp. 1955); Miss. Code ANN. $\$ 5310$ (Supp. 1954).

Most of the cases denying incorporation to nonprofit associations have arisen under the New York and Pennsylvania statutes. E.g., In re Voters Alliance for Americans of Ger- 
meaningful statutory standards exist, ${ }^{42}$ two vague criteria for exercising this power have developed: the principles of an association must be in accord with public policy, ${ }^{43}$ and the association must not conduct activities that are adequately performed by other organizations. ${ }^{44}$

The constitutionality of holding political associations to these two requirements may be questioned. Certainly, a state is not obligated to establish a privilege of incorporation for the class of political associations. But once any privilege is established for a class, its denial to any member of that class may constitute a denial of equal protection of law unless the distinction has a reasonable foundation. ${ }^{45}$ Thus, to allow the privilege of incorporation to some political associations precludes a state from arbitrarily denying that privilege to others. Furthermore, the denial may be an abridgment of free speech if the discrimination cannot be justified by a "substantial public purpose." 46 For denial of

man Ancestry, 64 N.Y.S.2d 298 (Sup. Ct. 1946) ; Citizens League of Whitfield, $65 \mathrm{~Pa} . \mathrm{D}$. \& C. 70 (C.P. 1949). See Note, 55 Colun. L. Rev. 380 (1955).

Political associations may encounter difficulty in incorporating even under general incorporation statutes. The standard provision extends incorporation to persons organizing to conduct "any lawful business" and thus equips officials with the power to deny incorporation to associations engaging in activities against the public policy of the state. See, e.g., Ala. Code Ann. tit. 10, \& 1 (Supp. 1955); Conn. Gen. Stat. $\$ 5151$ (1949). Thus action is still pending on the application of an organization with purposes similar to the ousted NAACP for incorporation in Alabama as the Guiding Voice, Inc. Southern School News, July, 1956, p. 9, col. 2 .

42. Where provided at all, statutory standards are in the most general terms. E.g., Mo. Rev. Stat. $\$ 352.050$ (Supp. 1956) (applicant's purpose in incorporating must be lawful and publicly useful) ; PA. Stat. ANN. tit. 15, $\$ 2851-207$ (Purdon 1955) (purpose must be lawful and not injurious to community); S.C. Code 12-756 (Supp. 1956) (applicant must not operate in violation of law).

43. In re Mazzini Cultural Center, 185 Misc. 1031, 58 N.Y.S.2d 529 (Sup. Ct. 1945); In re Patriotic Citizenship Ass'n, 53 N.Y.S.2d 595 (Sup. Ct. 1945) (group seeking to amend constitution to provide for forfeiture of citizenship by anyone distributing matter advocating violent overthrow denied charter); In re Incorporation of Nat'l Legion of Am. People, 38 Luzerne L.R. Rep. 78 ( $\mathrm{Pa} .1944$ ) (charter denied because applicant did not specify the political or economic philosophy it wished to disseminate).

44. Denials: In re Marine Corps Veterans Foundation, 79 N.Y.S.2d 18 (Sup. Ct. 1948) (organization seeking to increase loyalty); In re Voters Alliance for Americans of German Ancestry, 64 N.Y.S.2d 298 (Sup. Ct. 1946) (organization to educate in political thinking). Most of the cases using this rationale, however, deal with associations that are nonpolitical. E.g., Application of Knesseth Harabonin D'America, Inc., 131 N.Y.S.2d 543 (Sup. Ct. 1954) (orthodox rabbinical organization) ; Matter of Waldemar Cancer Research Ass'n, 205 Misc. 560, 130 N.Y.S.2d 426 (Sup. Ct. 1954) (charitable organization); In re Animal Protective \& Rescue League, 84 Pa. D. \& C. 537 (C.P. 1954).

45. Fowler v. Rhode Island, 345 U.S. 67 (1953) (denial of use of public park held unconstitutional) ; Niemotko v. Maryland, 340 U.S. 268 (1951) (same).

46. American Communications Ass'n v. Douds, 339 U.S. 382 (1950). The Court upheld the denial of the privilege of using the NLRB to unions whose officers refused to sign non-Communist affidavits. The Court, however, refused to accept the government's argument that the denial of a privilege could never constitute an abridgment of the First Amendment. Id. at 390. Instead the Court recognized that denial of NLRB facilities is a 
incorporation has the effect of placing the rejected applicant at a serious competitive disadvantage with incorporated associations. ${ }^{47}$ Fear of unlimited personal liability may keep persons from joining the unincorporated association; 48 lack of capacity to sue or hold property may weaken the organization finan-

significant burden for a union, and that as a result the non-Communist affidavit requirement would exert pressure on individuals in union leadership positions to abandon belief in Communism. Id. at 404. But the Court found the requirement constitutional because the need for regulation affecting interstate commerce outweighed the effect of the requirement upon the right to free speech. $I d$. at 411 . The Court also stressed the rational connection between the purpose of denying the NLRB's facilities to Communists and the purpose of the NLRB itself. For denial of the privilege of invoking the NLRB's help to unions whose officers are likely to engender political strikes subserves the privilege's purpose of promoting the free flow of interstate commerce. Id. at 404-06. See also United Public Workers v. Mitchell, 330 U.S. 75 (1947) (ban against political activities for government employees upheld; Court deferred to legislative determination that active political partisanship was inconsistent with an efficient civil service); Hannegan v. Esquire, Inc., 327 U.S. 146, 157-58 (1946) (dictum that Congress does not have unfettered power to discriminate in the award of the second class mail privilege).

In the above cases the Supreme Court departed completely from the approach suggested by Justice Holmes in McAuliffe v. New Bedford, 155 Mass. 216, 29 N.E. 517 (1892), that a discriminatory award of privileges would never be vulnerable to constitutional attack because "petitioner ... has no constitutional right to be a policeman." The only recent case reflecting this view is Adler v. Board of Education, 342 U.S. 485, 492 (1952) where in upholding a denial of public employment the Court stated in dictum that petitioners are "at liberty to retain their beliefs and associations and go elsewhere." Soon thereafter, however, the Supreme Court abandoned this rationale to circumscribe denials of public employment with the requirement of scienter. Weiman v. Updegraff, 344 U.S. 183 (1952). For discussion of privilege case's, see Wilcox, Invasions of the First Amendment Throngh Conditioned Public Spending, 41 CoRNel. L.Q. 12 (1945).

47. Burdens need not be prohibitive to abridge the First Amendment. See, e.g., Hannegan v. Esquire, Inc., 327 U.S. 146 (1946) (denied special mail rate); Murdock v. Pennsylvania, 319 U.S. 105 (1943) (payment of license fee of $\$ 1.50$ per day to solicit) ; Milwaukee Publishing Co. v. Burleson, 255 U.S. 407, 430-31. (1921) (dissent) (special mail rate); cf. American Communications Ass'n v. Douds, 339 U.S. 382 (1950) (denied privileges of NLRB).

48. Fear of personal liability for the debts of nonprofit associations is very often groundless. See note 36 supra. Nevertheless, unincorporated organization is so identified with unlimited liability that associations that can offer limited liability have a considerable advantage. Members of nonprofit corporations are not personally liable for debts of the corporation under many state statutes. See, e.g., Mo. Rev. Star. \& 352.120 (Supp. 1956); PA. Stat. ANn. tit. 15, \& 2851-610 (Purdon 1955). In absence of such statutes there is doubt as to whether limited liability exists, especially in view of the small capitalization of nonprofit corporations. See Larson, Comparison of Characteristics of Corporate and Unircorporated Nonprofit Assaciations, in 1951 REP. OF N.Y. LAw REvision Cosnr's 441.

A recent development attests to the disadvantages of unincorporated status. The growth of investment clubs is apparently being stunted by fear of unlimited liability. In many cases persons have been advised that they may be held liable for the personal debts of other members. See letter from Thomas E. O'Hara, Chairman, Board of Trustees, National Ass'n of Investment Clubs, to the Yale Law Journal, Oct. 18, 1956, on file in Yale Law Library. 
cially. 49 The two standards traditionally used to deny incorporation must therefore be measured against the requirement of a substantial public purpose. ${ }^{\text {.0 }}$

The objective of the first standard-conditioning incorporation on public approval of the principles advanced by an association-is to discourage the advocacy of ideas deemed offensive to the community. At most, however, the First Amendment permits a state to discourage the advocacy of ideas that are libelous, obscene, seditious or imminently provocative of serious violation of law..$^{51}$ Accordingly, a state may not base a denial of incorporation on disapproval of ideas that do not come within this category. ${ }^{52}$ The second standard, denying corporate charters if other political corporations are performing the

49. See note 30 supra and accompanying text. Not all states have eliminated these disabilities. 3 American LAw of Property $\$ 12.78$ (Casner ed. 1954 Supp.).

50. If a political association is applying for incorporation, it should be allowed to attack a denial of the privilege as a "person" under the Fourteenth Amendment. See notes 10-29 supra and accompanying text. If a previously unassociated group seeks incorporation, its individual members should be allowed to challenge a refusal to incorporate as a restriction on their right to speech. Cf. Hague v. CIO, 307 U.S. 496 (1939).

51. Chaplinsky v. New Hampshire, 315 U.S. $571-72$ (1942); Near v. Minnesota, 283 U.S. 697, 716 (1931) (dictum) ; Comment, 65 Yale L.J. 1159, 1178 n.99 (1956).

The Supreme Court has distinguished sharply between discriminations against particular ideas and discriminations that cut across all beliefs. Thus in upholding the ban on all political activities for government employees, the Court accepted counsel's argument that Congress may not "enact a regulation providing that no Republican, Jew or Negro shall be appointed to federal office. ..." United Public Workers v. Mitchell, 330 U.S. 75, 100 (1947). Congress or a state may discriminate against the same beliefs that they may punish, except that in the case of punishment imminence of danger from the advocacy must be shown. Compare Harisiades v. Shaughnessy, 342 U.S. 580 (1952) (privilege of residence may be denied to aliens belonging to organization advocating violent overthrow of government), American Communication Ass'n v. Douds, 339 U.S. 382 (1950) (upholding denial of use of NLRB to members of the organization) and Adler v. Board of Education, 342 U.S. 485, 492 (1952) (upholding denial of public employment to members of same organization), with Dennis v. United States, 341 U.S. 494 (1951) (upholding punishment of persons combining to advocate violent overthrow of government). Compare also Public Clearing House v. Coyne, 194 U.S. 497, 507 (1904) (dictum; obscene literature may be denied postal privilege), with New York v. Doubleday \& Co., 297 N.Y. 687, 77 N.E.2d 6 (1947), aff'd by equally divided Court, 335 U.S. 848 (1948) (upholding criminal sanctions against disseminators of obscenity), and Near v. Minnesota, 283 U.S. 697, 716 (1931) (dictum: "the primary requirements of decency may be enforced against obscene publications"). The Supreme Court has also allowed punishment of persons uttering libelous statements about a race or religion, Beauharnais v. Illinois, 343 U.S. 250 (1952), and persons making public addresses which incite to riot, Feiner v. New York, 340 U.S. 315, 321. (1950); Chaplinsky v. New Hampshire, 315 U.S. 568 (1941). Cf., Maryland Drydock Co. v. NLRB, 183 F.2d 538 (4th Cir. 1950) (upholding employer's ban on union newspaper libelous to employers).

52. See Joseph Burstyn, Inc. v. Wilson, 343 U.S. 495, 504-05 (1952) (profanity protected from prior restraint); Weiman v. Updegraff, 344 U.S. 183, 192-94 (1952) (concurring opinion) (state may not deny public employment to members of certain associations) ; Niemotko v. Maryland, 340 U.S. 268 (1951) (state may not deny use of park because of religious belief) ; Hannegan v. Esquire, Inc., 327 U.S. 146 (1946) (dictum that second class mail privilege may not be denied because of official's view that publication did not contribute to the public good); cf. Milwaukee Publishing Co. v. Burleson, 255 U.S. 
same function, can never be sustained. Unlike the public approval standard, the object of this criterion is to limit the number of corporations advocating particular ideas, not to discourage the dissemination of offensive ideas. ${ }^{53}$ But while restriction of economic competitors may be a legitimate purpose of incorporation laws, ${ }^{54}$ restriction of competitors in the political process is totally inconsistent with the First Amendment's goal of a free market place of ideas. Therefore, denial of incorporation to a political association merely because corporations with identical principles are in existence is an unconstitutional abridgment of the guarantee of free speech, and in addition a denial of equal protection of the law.

\section{Exclusion of Foreign Corporations}

While a local association which has been denied a corporate charter may continue to operate in unincorporated form, exclusion of an association that has been incorporated elsewhere precludes all its activities within the state. ${ }^{55}$ The doctrinal justification for the power to exclude is that a corporation is an arti-

407, 431 (1921) (Brandeis, J., dissenting) (second class mail privilege may not be denied because of Postmaster General's dislike of views).

A statute may be unconstitutional on its face if it affords officials the opportunity to discriminate against specific ideas. E.g., Kunz v. New York, 340 U.S. 290 (1950) (denied permit for street meetings to prevent disorder); Cantwell v. Connecticut, 310 U.S. 296 (1940) (license for public solicitation); Schneider v. State, 308 U.S. 1147 (1939) (prohibited handbill distribution to keep streets clean).

53. Indeed, the court may argue that the denial of incorporation strengthens the advocacy of a particular program:

"There are already a number of well established, respectable and representative veteran organizations performing all of the things that are proposed to be performed by this certificate of incorporation. By joining one of the already existing veteran organizations, the incorporators could more effectively and expediently accomplish their aims."

In re Marine Corps Veterans Foundation, Inc., 79 N.Y.S.2d 18 (Sup. Ct. 1948).

54. See Bank of Augusta v. Earle, 38 U.S. (13 Pet.) 519, 592-93 (1839) (state may protect local monopoly by excluding competitors incorporated elsewhere); HENDERSon, op. cit. supra note 38, at 21 (old view was that incorporation contemplated monopoly). But se Louis K. Liggett Co. v. Lee, 288 U.S. 517, 548, 553 (1933) (dissenting opinion) (incorporation laws used to prevent monopoly, e.g., by limiting amount of capital).

In New York Ice Co. v. Liebmann, 285 U.S. 262 (1.932), the Court held that a state may not restrict competition by requiring a license to engage in business not affected with the public interest. No occasion has arisen for reconciling the rationale for denying corporate charters with this decision. For under general incorporation laws businesses are freely incorporated. See note 40 supra and accompanying text.

Restricting the number of charitable organizations serving the same cause may be necessary to maximize success. For the public may be confused or irritated by the solicitations of a number of apparently indistinguishable charities. E.g., Matter of Waldemar Cancer Research Ass'n, 205 Misc. 560, 130 N.Y.S.2d 426 (Sup. Ct. 1954); In re Animal Protective and Rescue League, 84 Pa. D. \& C. 537 (C.P. 1952).

55. All states possess the power to exclude. National Council United Am. Mechanics v. State Council, 203 U.S. 151 (1906); Kansas ex rel. Griffith v. Ku Klux Klan, 117 Kan. 
ficial creation of local law which the foreign state is not bound to recognize under the rules of comity. ${ }^{56}$ Logically applied, this rationale would only authorize stripping a foreign corporation of the legal attributes of the corporate status. The agents of the unrecognized foreign corporation could be treated as principals or agents of an unincorporated association, and in either capacity permitted to conduct activities within the state. Nevertheless, the power to exclude has always been interpreted as the broad power to keep agents of the excluded corporation from conducting any activities within the state. ${ }^{\text {bi }}$ As a result, when a political association is excluded, a prior restraint, the most extreme form of First Amendment abridgment, occurs; ${ }^{58}$ the organization is denied the right to be heard, not merely punished for what it says. Thus any agent of the NAACP who addressed a meeting in Alabama or Texas, the states

564, 232 Pac. 254 (1925); Ku Klux Klan v. Virginia, 138 Va. 500, 122 S.E. 122 (1924). In most of the cases, however, the power is relied upon by a state in order to support some conditions which the state is imposing. E.g., Asbury Hospital v. Cass County, 326 U.S. 207 (1945) ; Phillips Petroleum Co. v. Jenkins, 297 U.S. 629 (1936) ; Washington ext rel. Bond v. Superior Ct., 289 U.S. 361 (1933).

For a discussion of the power to exclude, see Hexderson, op. cit. supra note 38; Merrill, Unconstitutional Conditions, 77 U. PA. L. Rev. 879 (1929); Comment, 59 Y ALE L.J. 73 (1951) ; Note, 79 U. PA. L. Rev. 956, 1119, 1129 (1931).

56. Paul v. Virginia, 75 U.S. (8 Wall.) 168 (1869); Bank of Augusta v. Earle, 38 U.S. (13 Pet.) 519 (1839) ; HENDERSon, op. cit. supra note 38, at 36-49. The better view is that the corporate entity is merely a fiction which is useful for some purposes such as amenability to suit, but which should be disregarded when policy considerations demand. Mason v. Mitchell, 135 F.2d 599, 600 (9th Cir. 1943) (dictum); Schmid v. First Camden Nat'l Bank, 130 N.J. Eq. 254, 22 A.2d 246 (Ch. 1941) (dictum); see Latty, The Corporate Enterprise as a Solvent to Legal Problems, 34 Mrce. L. Rev. 597 (1936). But opinions rarely articulate the policy considerations that justify exclusion. See, e.g., Magna Oil \& Refining Co. v. White Star Refining Co., 280 Fed. 52 (3d Cir. 1922) ; F. E. Nugent Funeral Home, Inc. v. Beamish, 315 Pa. 345, 173 Atl. 177 (1934). But cf. Atlantic Refining Co.v. Virginia, 302 U.S. 22 (1937).

57. Historically, power to exclude was used to protect local monopolies from foreign competition. The object of exclusion, therefore, was to keep out foreign enterprises altogether, not merely to confer a competitively disadvantageous unincorporated status on them. HeNDERSon, op. cit. supra note 38, at 101-02.

Moreover, even if a state were satisfied to allow an unincorporated enterprise to do business locally there would be insuperable jurisdictional barriers to effectively disregarding a foreign corporate form. For example, if the shareholders reside out of state, they could not be held personally liable as members of an unincorporated association unless their state paradoxically honored the excluding state's nonrecognition of the corporate form.

Furthermore, while nonrecognition of corporations does not violate the full faith and credit clause of the Constitution, one commentator has suggested that refusal to recognize an attribute of a corporation that is derived from the incorporation of another state, such as limited liability, would be a violation. Holt, Full Faith and Credit-A Suggested Approach to the Problem of Foreign Corporations, 89 U. PA. L. REv. 453, $478-79$ (1941).

58. Exclusion works a greater restraint than what has been labeled a prior restraint in other cases because it is a bar to all operations and not merely to a phase of operations as in, e.g., Saia v. New York, 334 U.S. 558 (1948) (prohibition of loudspeakers); Jamison v. Texas, 318 U.S. 413 (1943) (prohibition of handbills); Cox v. New Hampshire, 312 U.S. 569 (1941) (restriction on parades). 
from which the association was ousted by court injunction, would be subject to criminal contempt. ${ }^{59}$ Moreover, local incorporation laws offer no realistic escape from this prior restraint. For political associations excluded from a state on public policy grounds have little chance of obtaining local charters; ${ }^{60}$ and even if they did, the costs of multiple incorporation might be prohibitive. ${ }^{61}$

Although not all prior restraints are forbidden by the First Amendment, ${ }^{62}$

59. See decrees cited note 5 supra. The lack of a sure ritual for shedding agency relationship may result in the abridgment of the right of persons associated with the NAACP to speak in their individual capacities. Intention of the parties is the basis of an agency relationship. MIECHEM, AGENCY $\$ 30$ (2d ed. 1941). But stated intention need not be controlling, for a court may conclude that a disclaimer of agency was a subterfuge. $C f$. Darker v. Colby, 375 III. 558, 31 N.E.2d 950 (1941) (formal contract for relationship as independent contractors disregarded by court in finding agency relationship). Thus in determining whether a speaker is really acting as agent for an excluded corporation, courts may logically look to the content of his speeches. Accordingly, if members or employees of an excluded corporation speak in their individual capacity on causes promoted by the corporation, they risk being found to have acted as agents and punished for contempt. Faced with this danger, individuals must either remain silent in the excluding state, or resign membership or employment in the excluded corporation: a choice which is repugnant to freedom of speech.

60. See notes 38-44 supra and accompanying text. The application for incorporation of an organization with purposes similar to that of the NAACP is pending in Alabama. See note 41 supra. Even if the denial of incorporation would be unconstitutional, a state may avoid the adjudication by delaying action on the application. Cf. Note, $104 \mathrm{U}$. PA. L. REv. 974 (1956) (establishment of administrative tribunal to delay federal review).

61. A state may require a foreign corporation to incorporate locally in order to do intrastate business within its borders. Railway Express Agency, Inc. v. Virginia, 282 U.S. 440 (1931). While the cost of incorporating in one other state may be insignificant, costs loom large when a corporation does a nationwide business. Thus the Supreme Court has held that if a corporation is engaged in interstate commerce, it would be an unconstitutional burden upon such commerce to require local incorporation. Railway Express Agency, Inc. v. Virginia, supra; Dahnke-Walker Milling Co. v. Bondurant, 257 U.S. 282 (1921). Similarly it would seem that the exercise of free speech is abridged by requiring a political corporation engaged in nationwide activities to bear the burden of incorporation in another state. Cf. AFL v. Reilly, 113 Colo. 90, 155 P.2d 145 (1945).

Moreover if the court finds that a foreign corporation is a "person" within the Fourteenth Amendment, see notes 10-29 supra and accompanying text, it should be entitled in that capacity to freedom from prior restraint. Accordingly, it is arguable on doctrinal grounds that a state violates the free speech guarantee when it admits a foreign corporation only on condition that it then become a local corporation. For the foreign and domestic corporations are separate entities and although the domestic "person" would be free to conduct First Amendment activities, its foreign alter ego would not. The Supreme Court has ruled, however, that a foreign corporation required to incorporate locally retains its foreign capacity for diversity of citizenship jurisdiction. Railway Express Agency, Inc. v. Virginia, supra; Southern Ry. v. Allison, 190 U.S. 326 (1903). See Note, 44 HaRv. L. REv. 428 (1931). Similarly, when faced with a prior restraint argument, the court might rule that a foreign corporation admitted as a domestic corporation is functioning within the state.

62. Advocacy of particular ideas may be restrained, but there is little case law precisely defining this area. See Near v. Minnesota, 283 U.S. 697, 716 (1931) (dictum) which 
exclusion of a political corporation will rarely meet the strict requirements of constitutionality. First, prior restraints must be imposed pursuant to a clearly defined statutory standard. ${ }^{63}$ In most states, however, the only administrative guide for determining whether to exclude foreign corporations is the administrator's conception of public policy. ${ }^{64}$ Secondly, a prior restraint can be upheld only if a substantial public purpose will be served and if a less restrictive abridgment is not available. ${ }^{65}$ If subsequent punishment would serve the same purpose, the advocate must be given the opportunity to speak $;^{60}$ or if a lesser prior restraint would accomplish the same end, the greater restraint is unconstitutional. ${ }^{67}$ The alleged purpose for excluding political corporations has usual-

permits restraint of advocacy that obstructs the war effort, or is obscene or scditious; Chaplinsky v. New Hampshire, 315 U.S. 568, 571-72 (1942) (dictum) which permits prevention and punishment of "the lewd and obscene, the profane, the libelous, and the insulting or 'fighting' words-those which by their very utterance inflict injury or tend to incite an immediate breach of the peace." Prior restraint of profanity has been denied. Joseph Burstyn, Inc. v. Wilson, 343 U.S. 495 (1952). Prior restraint of wartime speech and obscenity have never been passed on. Cf. Schenk v. United States, 249 U.S. 47 (1919) (subsequent punishment of speech interfering with war effort) ; Joseph Burstyn, Inc. v. Wilson, supra (avoided obscenity point). On sedition see Communist Party v. Subversive Activities Control Bd., 223 F.2d 531, 557 (D.C. Cir. 1954) (dictum; ban of organization advocating violent overthrow), rev'd on other grounds, 351 U.S. 115 (1955) ; cf. Dennis v. United States, 341 U.S. 494 (1951) (subsequtnt purishment of advacacy of violent overthrow).

An exception to the proscription of prior restraints has also developed where there is no discrimination against specific ideas and the restraint is necessary to the proper allocation and use of a privilege. Saia v. New York, 334 U.S. 558 (1.948) (dictum; hours and place of use of sound trucks) ; Cox v. New Hampshire, 312 U.S. 569 (1941) (traffic control). These restraints actually enhance efficient communication.

See Emerson, The Doctrine of Prior Restraint, 20 LAw \& Contenr. Proz. 648 (1955).

63. See, e.g., Kunz v. New York, 340 U.S. 290, 293 (1951) ; Niemotko v. Maryland, 340 U.S. 268 (1951) ; Saia v. New York, 334 U.S. 558 (1948) ; Cox v. New Hampshire, 312 U.S. 569 (1941).

64. Some states exclude on the basis of foreign corporation statutes, but the standards, if any, are very vague. E.g., GA. CodE ANN. \$22-1502 (Supp. 1955) ("no foreign corporation shall exercise within this state any corporate power or privilege which is contrary to the public policy of the state") ; KaN. GEN. STAT. $\$ 17-503$ (1949) ("organized for a purpose for which a domestic corporation may be formed"), Kansas ex rel. Griffith v. Ku Klux Klan, 117 Kan. 564, 232 Pac. 254 (1925).

When exclusion is derived from common law, only the vague concept of public policy guides its use. Bank of Augusta v. Earle, 38 U.S. (13 Pet.) 519, 591-92 (1839) ; National Council United Am. Mechanics v. State Council, 203 U.S. 151 (1906).

65. E.g., Niemotko v. Maryland, 340 U.S. 268, 272 (1951) ; Saia v. New York, 334 U.S. 558 (1948) ; Cox v. New Hampshire, 312 U.S. 569, 575 (1941.). See Comment, 65 YALE L.J. 1159 (1956).

66. Kunz v. New York, 340 U.S. 290, 294-95 (1950) (subsequent punishment adequate); Schneider v. State, 308 U.S. 147 (1939) (same).

67. Martin v. City of Struthers, 319 U.S. 141, 148 (1943) (state may protect public from annoyance of solicitors, but solicitors may only be forbidden from approaching those individuals who indicate they are unwilling to be disturbed). 
ly been the prevention of illegality and violence. ${ }^{68}$ Even if a state could restrain advocacy of unlawful conduct, ${ }^{69}$ exclusion of a political corporation ordinatily restrains advocacy of lawful conduct as well. For, as in the case of the NAACP, most political associations urge policies that a state does not or could not contend are illegal. ${ }^{70}$ Since a less restrictive but functionally equivalent abridgment would be to admit the corporation and then to enjoin any unlawful advocacy, the broader restraint of exclusion is unconstitutional.

Moreover, the traditional policy rationale for the exclusionary power yields no justification for the prior restraint of political associations. In upholding state regulation of foreign commercial corporations, the Supreme Court has stressed that a state must have the exclusionary power to maintain the integrity of its incorporation laws $\mathbf{~}^{\mathbf{7 1}}$ in the absence of this power, persons could circumvent a prohibitive local incorporation law by obtaining a charter from another state. This rationale, however, is of limited utility in justifying the exclusion of political associations, for once a state makes incorporation available to one association, its power to deny incorporation to other associations is greatly restricted. $^{.2}$ And if a state cannot refuse to incorporate an association, exclusion of that association as a foreign corporation cannot be considered essential for the preservation of local policy. But even if the circumstances were such that a state could constitutionally deny local incorporation to the foreign corporation, ${ }^{73}$ the interest in maintaining local incorporation policy appears too insubstantial to justify a prior restraint of free speech. ${ }^{74}$

68. Kansas exr rel. Griffith v. Ku Klux Klan, 117 Kan. 564, 568, 232 Pac. 254, 256 (1925) (findings of threats and intimidation of public); cf. Ku Klux Klan v. Virginia, 138 Va. 500, 122 S.E. 122 (1924). The basis of the action against the NAACP was that the organization encouraged violation of segregation laws. The failure of the NAACP to register does not seem to be the essence of the complaint since the NAACP was also enjoined from registration. See note 5 supra.

69. See note 51 stipra.

70. Inasmuch as segregation is unconstitutional, Gayle v. Browder, 352 U.S. 903 (1956) (busses) ; Brown v. Board of Education, 347 U.S. 483 (1954), a state should not be able to restrain advocacy of integration.

71. Bank of Augusta v. Earle, 38 U.S. (13 Pet.) 519 (1839); Paul v. Virginia, 75 U.S. (S Wall.) 168 (1868) ; see Comment, 59 Yale L.J. 737 (1950); cf. Kan. Gen. Stat. $\$ 17-503$ (1949) (a foreign corporation must be organized for a purpose for which a domestic corporation could be organized). The policy of protecting local incorporation laws antedates the "race of laxity," note 39 supra. But since this race is long over, and relatively slight and uniform restrictions on incorporation now exist, see note 40 supra, this policy is no longer a valid one.

72. See notes 30-54 supra and accompanying text.

73. Apart from circumstances under which discrimination against an organization might be constitutional, see notes 51,52 supra and accompanying text, a denial would be constitutional if states denied the privilege of incorporation to political associations as a class.

74. The substantiality of purpose necessary to justify a restraint upon free speech depends on the extent of the restraint. Most cases deal with partial restraints. E.g., Kunz v. New York, 340 U.S. 290 (1951) (protection of peace and order of community from violence or disorder which may result from speech does not justify restraint on public 


\section{Identification of Members}

Registration statutes that require local and foreign political associations to publish their membership lists furnish states with another means of controlling advocacy of an ideology. Although these statutes may apply indiscriminately to all political associations, ${ }^{75}$ their burden will fall more probably than not on those organizations disapproved by the state. ${ }^{76}$ Associations in political favor can reveal the names of members without jeopardizing their welfare, but organizations representing unpopular minorities risk subjecting the persons identified as members to official and private sanctions ranging from loss of public employment and economic boycotts to violence. ${ }^{77}$ In the face of such sanctions, the association can expect a loss of existing and potential membership resulting in a weakening of political effectiveness. It is not surprising,

meeting) ; Martin v. City of Struthers, 319 U.S. 141 (1943) (possibility of crime and annoyance from soliciting door to door does not justify restraint); Schneider v. State, 30S U.S. 147 (1939) (clean streets and good appearance do not justify restraining distribution of circulars).

In the case of exclusion of a foreign corporation, the restraint is total and other means cannot be employed to disseminate ideas in that state. Therefore, the purpose would have to be greater than in most cases.

Relevant analogies may be drawn from cases discussing the power of states to affect interstate commerce. In general, a state may not require a foreign corporation to secure a license or permit to transact business which is in interstate commerce. Sioux Remedy Co. v. Cope, 235 U.S. 197 (1914); Barrett v. New York, 232 U.S. 14 (1914); International Textbook Co. v. Pigg, 217 U.S. 91 (1910) ; Crutcher v. Kentucky, 141 U.S. 47 (1891). As in the First Amendment cases the protection of interstate commerce is not absolute; it is often necessary to balance the goal of uniformity in interstate commerce against the substantiality of the local purpose. Southern Pacific Co. v. Arizona ex rel. Sullivan, 325 U.S. 761 (1945).

75. See LA. Rev. Stat. $\$ 12: 401-5$ (Supp. 1955) requiring membership lists of every type of organization, incorporated and unincorporated and N.C. GEN. STAT. $\$ \$ 120-48$ to 55 (Supp. 1955) requiring membership lists of all organizations influencing legislation or public opinion. There is indication however that the Louisiana statute is not actually invoked against all of the organizations included within its language. Jennings v. Lester, 76 So. $2 \mathrm{~d} 91$ (La. 1954) (law enacted primarily to regulate $\mathrm{Ku} \mathrm{Klux} \mathrm{Klan).} \mathrm{If} \mathrm{the} \mathrm{statute}$ is discriminately applied other constitutional problems are raised. See, e.g., Yick Wo v. Hopkins, 118 U.S. 356, 373-74 (1886) (denied permits to operate laundry to persons of Chinese origin) ; Norris v. Alabama, 294 U.S. 587, 589 (1935) (exclusion of Negroes from jury).

76. Indeed, the Ku Klux Klan was the target of "non-discriminatory" statutes requiring identification of membership lists. See Jennings v. Lester, supra note 75 (Louisiana registration statute).

77. The Georgia Board of Education has threatened to revoke the license of any teacher who remains a member of the NAACP, N.Y. Times, Aug. 2, 1955, p. 13, col. 3, although the order was subsequently modified leaving the matter to local authorities, id., Aug. 16, 1955, p. 25, col. 2. See statement of Roy Wilkins, executive secretary of the NAACP, that NAACP members have been "subjected to economic pressure and personal threats and acts of violence." Id., July 26, 1956, p. 11, cols. 3-4.

In Louisiana and South Carolina membership in the NAACP by government employees, including teachers, is illegal. Southern School News, Jan. 1957, p. 2, col. 1. 
therefore, that the NAACP, an organization particularly disfavored by dominant groups in the South, has generally refused to reveal its membership lists. ${ }^{78}$

Precedent might on first impression support a statute requiring identification of members in political organizations as a valid exercise of regulatory power. In Bryant v. Zimmerman, ${ }^{79}$ decided in 1928, the Supreme Court held that a state could compel a local unincorporated chapter of the Ku Klux Klan to reveal its members. Attacked on due process grounds, the statute was found "not arbitrary or oppressive, but reasonable and likely to be of real effect."80 The Court felt that the restrictive effect of the statute would be socially desirable, since the regulation tended to discourage criminal activity. ${ }^{81}$

Although the Court's reasoning supports state control, its thrust is seriously undercut by later cases pointing to the deterrent effect of identification on free speech, ${ }^{82}$ a factor unmentioned in Bryant. Even if the deterrence resulting from disclosure is actually effected by private rather than legal sanctions, registration is unconstitutional unless strictly related to a substantial public purpose. ${ }^{83}$

78. See note 6 supra. In New Orleans where the risk of private sanctions is minimal, the local branch has decided to register. See N.Y. Times, Dec. 31, 1956, p. 16, col. 4.

79. 278 U.S. 63 (1928). The statute in question required registration of oath-bound organizations with over twenty members, and then exempted all well known oath-bound organizations except the Klan from its purview. Id. at 63, 73.

80. Id. at 72. It is not clear whether the violation of due process alleged was a deprivation of free speech. But the Court did not treat it as such: "The relator's contention under the due process clause is that the statute deprives him from exercising his right of membership in the association." Ibid.

The statute was also attacked as a denial of equal protection of law and found constitutional. Id. at 77 .

81. Id. at 72. The Court did not note that the exposure of names might also have a deterrent effect on free speech. The explanation for this oversight may lie in the state court's finding that the Klan engaged substantially in terrorizing other individuals. Id. at 75. Or perhaps the explanation lies in the fact that this was the period before the Supreme Court was willing to challenge the balance between free speech and police powers struck by a state. Compare Gitlow v. New York, 268 U.S. 652 (1925), with De Jonge v. Oregon, 299 U.S. 353 (1937).

See also Burroughs v. United States, 290 U.S. 534 (1934) (Federal Corrupt Practices Act; no First Amendment issue) ; Lewis Publishing Co. v. Morgan, 229 U.S. 288 (1913) (disclosure requirement of Postal Law). See, generally, Smith, Democratic Control of Propaganda throngh Registration and Disclosure, 6 PuBLIc OpINIon Q. 27 (1942).

\$2. United States v. Harriss, 347 U.S. 612, 625-26 (1954) (narrow construction of Regulation of Lobbying Act) ; United States v. Rumely, 345 U.S. 41, 46 (1953) (narrow interpretation of resolution authorizing investigation of lobbying); American Communications Ass'n v. Douds, 339 U.S. 382, 402 (1950) (non-Communist oath requirement); Thomas v. Collins, 323 U.S. 516 (1945) (registration of labor organizer); Communist Party v. Subversive Activities Control Bd., 223 F.2d 531, 544 (D.C. Cir. 1954) (registration provision of Subversive Activities Control Act realistically restricts expression), rev'd on other grounds, 351 U.S. 115 (1955). But see United States v. Peace Information Center, 97 F. Supp. 255, 262 (D.D.C. 1951) (Foreign Agents Registration Act).

83. American Communication Ass'n v. Douds, 339 U.S. 382, 402 (1950):

'... indirect 'discouragements' undoubtedly have the same coercive effect upon the exercise of First Amendment rights as imprisonment, fines, injunctions or taxes. A 
Thus, in Thomas v. Collins ${ }^{84}$ the Supreme Court held that a union organizer could not be required to register as a condition to addressing a group of workers. In United States $v$. Harriss ${ }^{85}$ the Court held that a necessity for evaluation of pressures upon Congress justified the registration of all persons receiving or expending money "to influence directly or indirectly the passage or defeat of legislation by Congress." 86 The Court, however, restricted the act to persons making direct representations to Congress because application to organizations seeking to propagandize the general public might violate the First Amendment. ${ }^{87}$ Recently, a lower court held that an organization claiming to be within the class exempted from the lobbying law by Harriss may be required to file membership lists under another statute. ${ }^{88}$ Finding that the Communist Party presented a clear and present danger of violent overthrow of the government and could therefore be outlawed, the court upheld the disclosure provisions of the Subversive Activities Control Act.

State statutes requiring membership lists from all political associations raise the very constitutional issue avoided by Harriss and not presented by the Communist Party case. These statutes are not aimed at a specific organization considered to be a threat to the security of the public. Rather, they exert their restraining force on any organization with unorthodox principles. In accordance with a current trend, courts could refuse to determine whether these statutes are unconstitutional on their face; instead they could confine their inquiry to whether the statutes are unconstitutional as applied to the particular organization refusing to register. ${ }^{89}$ But this adiudication would not relieve the deterrent effect of registration on organizations not represented in the proceedings. For until the constitutionality of applying the statute to the particular organization is determined, persons must act at their peril in joining. Thus,

requirement that adherents of particular religious faiths or political parties wear identifying arm-bands, for example, is obviously of this nature."

See United States v. Harriss, 347 U.S. 612 (1954); United States v. Rumely, 345 U.S. 41 (1953) (disclosure of individuals who influence public through pamphleteering).

84. 323 U.S. 516,539 (1945) :

"Lawful public assemblies, involving no element of grave and immediate danger to an interest the state is entitled to protect, are not instruments of harm which require previous identification of the speakers. And the right either of workmen or of unions ... to assemble and discuss their own affairs is as fully protected as the right of ... political party members. ..."

85. 347 U.S. 612 (1954).

86. Federal Regulation of Lobbying Act, 60 STAT. 839 (1946), 2 U.S.C. $\$ \$ 261,266-67$

(1952). (Emphasis added.)

87. 347 U.S. at 621,626 .

88. Communist Party v. Subversive Activities Control Bd., 223 F.2d 531 (D.C. Cir. 1954), rev'd on other gronnds, 351 U.S. 115 (1955) (remanded to Board for reconsideration in light of new evidence); Subversive Activities Control Act of 1950, 64 STAт. 987. 50 U.S.C. $\$ \$ 781,787$ (1952).

89. Cf. Dennis v. United States, 341 U.S. 494, 516 (1951) ; American Communications Ass'n v. Douds, 339 U.S. 382 (1950). 
activities of associations will be restrained even in cases where direct application of registration statutes would be declared unconstitutional. Because of this indiscriminate effect, statutes requiring membership lists from all political associations violate the First Amendment, whether or not they are constitutional as applied to a particular association. ${ }^{80}$

However, constitutional limitations on state power to interfere with free speech do not immunize associations engaging in lawful advocacy from all demands for the production of information. For example, state statutes requiring foreign corporations to designate an agent for service of process fulfill a legitimate purpose in facilitating enforcement of legal rights by residents. ${ }^{91}$ But these statutes need not, and hence cannot, be implemented by a requirement that the association furnish a list of local members to determine whether registration of an agent is mandatory. ${ }^{92}$ The Supreme Court has also noted that in the interest of safeguarding the public from fraud, states may require public solicitors of funds to produce credentials from the group they purport to represent. ${ }^{93}$ This purpose may also be effectuated without requiring the names of members of the solicitor's association or of those whom he enlists in his cause. ${ }^{94}$

But the fact that a warrant for identification can be found in one of the many state regulatory powers should not by itself determine constitutionality. A court order, such as was recently issued against the NAACP in Georgia, requiring the production of records for tax investigation, exemplifies this type of problem. ${ }^{15}$ Such a demand may be necessary to determine whether an or-

90. Where statutes exert a restraining influence on protected as well as unprotected speech, the Supreme Court has found them unconstitutional on their face. E.g., Cantwell v. Connecticut, 310 U.S. 296, 307 (1940) ; Thornhill v. Alabama, 310 U.S. 88, 97-99 (1939); Lovell v. Griffin, 303 U.S. 444, 450-51 (1937).

If a corporation is compelled to register, it should have standing to assert an abridgment of First Amendment rights. See notes 10-29 supra and accompanying text.

91. All states have such requirements. 17 FlETCHER, CyCL. CoRP. $\$ 8455$ (1932). In order to be required to register a corporation must be "doing business" within the state. Moreover if a corporation has certain minimum contacts with a state it may be subjected to in personam jurisdiction, whether or not it has registered an agent. International Shoe Co. v. Washington, 326 U.S. 310 (1945) ; St. Clair v. Cox, 106 U.S. 350 (1882). See, generally, Note, Jurisdiction Over Foreign Corporations-An Analysis of Due Process, 104 U. PA. L. Rev. 381 (1955).

So long as these statutes are limited to registration of information and do not confer the power to deny the right to do business they are constitutional as to political corporations. See notes 55-74 supra and accompanying text.

92. Alabama has demanded the membership lists of the NAACP incident to determining whether they are doing business under the foreign corporation laws. See note 6 supra.

93. Murdock v. Pennsylvania, 319 U.S. 105, 116 (1943) (dictum); Cantwell v. Connecticut, 310 U.S. 296, 306 (1940).

94. In Thomas v. Collins, 323 U.S. 516, 540-41. (1945) the Court held that the solicitation of funds may be subject to reasonable regulation so long as the right to free speech is not interfered with.

95. Williams, Rev. Comm'r of Georgia v. NAACP, reported in Southern School News, Dec. 1956, p. 10, col. 1. The grounds for the order were that the NAACP had 
ganization claiming exemption from state taxation as a nonprofit organization is distributing earnings to members. ${ }^{96}$ Yet it is apparent that the order may also be a means of obtaining a list of members and contributors for the purpose of extra-legal sanctions. Unless such blacklisting of unpopular groups can be prevented, decisions protecting the members of an association from other types of punishment or prior restraint will serve merely as invitations to accomplish the forbidden end through investigatory powers. ${ }^{97}$

In order to prevent an improper use of regulation, the Supreme Court has in the past probed the purposes of state action. In Grosjean v. American Press $\mathrm{Co}^{98}$ the Court ruled that an excise tax on advertising in newspapers with a circulation over a certain amount was unconstitutional as a "deliberate and calculated device in the guise of a tax to limit the circulation of information to which the public is entitled in virtue of the constitutional guarantees." Dis Disdaining the stated purpose of the tax, ${ }^{100}$ the Court took judicial notice that the tax was not one of the "ordinary forms of taxation for the support of government."101

neither filed a state income tax return nor applied for tax exemption. The court order banning the NAACP in Texas contains a finding that the NAACP was a profit-making organization that had evaded state taxes. Southern School News, Nov. 1956, p. 8, col. 2. But see opinion of Jacob K. Javits, Attorney General of New York State, that the NAACP and its legal division can be properly classified as nonprofit organizations, 1 RACE RELATTONS L. REP. 1164 (1956).

96. A normal requirement for tax exempt status under state and federal law is that net earnings not inure to the benefit of shareholders or other private individuals. See, e.g., INT. Rev. CODE of 1954, § 501(c) (3) ; GA. CODE ANN. § 92-3105(c) (Supp. 1955). The records of an organization's total income, including dues from members, may be necessary to determine whether this requirement has been satisfied. Even if such an investigation could be conducted without obtaining the names of members paying the dues, the record books will ordinarily contain this information. Moreover, a state may wish to question members to determine whether they are actually receiving dividends from the organization.

97. On the effectiveness of exposure as a deterrent to free speech, see notes 77-78 supra and accompanying text.

98. 297 U.S. 233 (1936). See notes 10-29 supra and accompanying text for a discussion of cases holding that corporations are "persons" within the meaning of the due process clause. The First Amendment limitation on the taxing power may be unique: "unless there are provisions extraneous to any tax need, courts are without authority to limit the exercise of the taxing power." United States v. Kahriger, 345 U.S. 22, 31 (1953) (federal "bookie" tax held not to violate the Tenth Amendment).

99. 297 U.S. at 250 . Louisiana had imposed a $2 \%$ tax on advertising in newspapers with a circulation of over 20,000 copies per week.

100. The purpose of the tax was alleged to be the raising of revenue for the support of the government. See Argument for Appellees, id. at 236.

101. Id. at 250-51. The Court stated:

"In view of the persistent search for new subjects of taxation, it is not without significance that, with the single exception of the Louisiana statute, so far as we can discover, no state during one hundred fifty years of our national existence has undertaken to impose a tax like that now in question." 
Aware that identification also imperils free speech, courts should require states to exhaust all other enforcement methods that would not effect such restrictions. ${ }^{102}$ If alternatives do not exist, the courts should then consider whether the state's interest in the information warrants the risk to free speech. ${ }^{103}$ Finally, where the public purpose served by identification outweighs the deterrent effect on protected activities, the courts must nevertheless be assured that disclosure be employed solely for the approved purpose. If the state court does not fulfill this responsibility, and the organization can prove

102. For a discussion of the least restrictive abridgment approach in the context of prior restraints, see notes $65-70$ supra and accompanying text. See also notes $91-93$ supra and accompanying text. For a general discussion of the theory, see Comment, 65 YALE L.J. 1159, 1173-75 (1956).

103. Concurring in Whitney v. California, 274 U.S. 357, 372, 377 (1927), Justice Brandeis stated that "prohibition of free speech and assembly is a measure so stringent that it would be inappropriate as the means of averting a relatively trivial harm to society." In his view the Court would be the judge of the gravity of the harm. The Court has adopted this role of quantitatively appraising the public interest in a regulatory measure, even in cases involving indirect abridgments of free speech resulting from the denial of a privilege. See American Communications Ass'n v. Douds, 339 U.S. 382, 400 (1950):

"In essence, the problem is one of weighing the probable effects of the statute upon the free exercise of the right of speech and assembly against the congressional determination that political strikes are evils of conduct which cause substantial harm to interstate commerce."

If a state's power to levy a tax is limited by the First Amendment, Grosjean v. American Press Co., 297 U.S. 233 (1936), certainly the power to investigate observance of tax laws is so limited. A court may conclude that under certain circumstances the risk to free speech inherent in revelation of records containing members' names outweighs a state's interest in discovering whether a political association is observing the tax laws. This would be especially true if the group is so vulnerable to the dominant opinion in the community that exposure of members would be fatal to its operations, and if the revenueproducing activities of the organization appear such that any tax liability would be minimal.

Compulsory production of records for tax investigation may also constitute a violation of the privilege against self-incrimination, a guarantee included within the due process clause of the Fourteenth Amendment, Twining v. New Jersey, 211 U.S. 78 (1908). See Kostelanetz, Bill of Rights Not Repealed for Taxpayers, 34 TAXEs 16, 17 (1956). But the Supreme Court has held that the privilege neither shields certain records required to be kept by law, Shapiro v. United States, 335 U.S. 1 (1947) (records required by OPA), nor obtains to corporations or quasi-corporate private associations, United States v. White, 322 U.S. 694 (1944) (records of labor union must be surrendered by custodian). See Meltzer, Required Records, The McCarrans Act, and the Privilege against Self-Incrimination, 18 U. CHr. L. REv. 687 (1951.). Although these holdings may foreclose Fifth Amendment protection against demands for the records of a political association, they should not stand in the way of First Amendment protection. For in view of the paramount inportance of the First Amendment to an open political process and the relatively insignificant number of profit-making organizations that would be entitled to First Amendment protection of records, the balance between individual rights and state interest in law enforcement need not be the same as in Fifth Amendment cases. On the priority of constitutional rights, see United States v. Carolene Products Co., 304 U.S. 144, 152 n.4 (1938). 
that membership lists are being used for the purpose of subjecting its members to sanctions, federal protection must be forthcoming.

\section{Conclusion}

The absence of clearly defined limitations upon state power to regulate political associations is attributable more to self-restraint in not employing this power than to the inadequacies of the Constitution. If, as in the case of the NAACP, states begin to invoke this power, First Amendment limitations wiil be drawn. Neither the traditional commerce powers to grant incorporation and to banish foreign corporations, nor the more novel powers to require identification of members, can be used to impair political activities under the guise of regulation. 